\title{
A Brief Account of the Relation between Prudence and Decision in Aristotle's Nicomachean Ethics
}

\author{
Aristotelesin 'Nikomakhos'a Etik' Eserinde Karar ve Basiret Arasindaki \\ İliskinin Kusa Bir İzahı \\ YAKUP HAMDİOĞLU \\ Cumburiyet University

Received: 19.02.15 Accepted: 13.04.15

Abstract: Aristotle's ethical theory tells us how happiness gives shape to the human life. Happiness containing within itself the effort toward the end especially manifests itself in using the tools, which will enable us to acquire our ultimate end, skillfully. This study aims to give a brief account of how the relationship between prudence and decision, which correspond to two of these tools, is established in his Nicomachean Ethics for understanding the conceptual framework of his moral philosophy.

Keywords: Aristotle, Nicomachean Ethics, ecision, prudence, happiness, virtue, soul. 
"For one swallow does not make spring, nor does one day; nor, similarly, does one day or a short time make us blessed and happy."

(Aristotle, NE: I098a2I-2)

It could serve a convenient starting point to note that literature abounds with numerous analyses, which take Aristotle to be among first-rate philosophers as far as the history of philosophy is concerned. His monumental impact on the direction of medieval philosophy, modern philosophy and contemporary philosophy is unquestionable. His critical questions and creative thoughts in metaphysics, political philosophy, ethics, theory of knowledge and logic have influenced almost all of the subsequent philosophers. He has a systematic attitude to philosophy, and throughout his philosophical oeuvre, he put a premium on "why?" (dia $t i$ ) question. As he puts it, reasoning, which goes with a why-question, crystallizes the difference between theoretical thought (theoretikos nous) and practical thought (praktikos nous) that are the basic forms of the activities of human being. This differentiation on which his main works put great store leads him to set apart two distinct reasons from each other, and to analyze whyquestions in the light of this basis.

Aristotle clearly argues that theoretical reasoning works to acquire the truth. It is merely a knowing for the sake of knowing. He makes clear this in Metaphysics' famous first phrase: "All human by nature desire to know." (Aristotle, 1997a: 980a22). Theoretical reasoning gives rise to theoretical sciences. According to Aristotle, they deal with beings themselves as beings. He regards metaphysics, mathematics and physics as three theoretical sciences. As for practical reasoning, it is about contingent elements. Its aim is to achieve the highest good (summum bonum), so it works to acquire action, which is an end in itself. Aristotle distinguishes practical sciences into three different branches: ethics, economy, and politics. According to him, highest practical science is politics, and ethics is essential part of it. For him, ethics is teleological because each action seems to aim at the ultimate end, which is valuable in itself. In accordance with his predecessors' ethical directions, he also grants that 
the aim of life is happiness (eudaimonia). Although happiness occupied the central point of Greek ethics, the question 'what is the reality of happiness in the human life or the ends of human life?' didn't meet with a serious philosophical investigation. That is exactly what Aristotle's $\mathrm{Ni}$ comachean Ethics ${ }^{\mathrm{I}}$ is in pursuit of.

When we evaluate $N E$ thoroughly, we will see that Aristotle defines happiness as rational activity, which corresponds to virtue. Prima facie, this may seem a vague definition. Above all, as several Aristotle's scholars emphasize, it is quite confusing to take happiness as the counterpart of 'eudaimonia'. 'Eudaimonia' etymologically comprises of the prefix 'eu', which indicates 'good' or 'well-being', and the word 'daimon', which amounts to 'guiding spirit' or 'guardian deity'. Therefore, daily use of 'eudaimonia' signifies the condition of 'high spirit', which lasts longer than pleasure. 'Eudaimonia' defined in this sense by the ancient Greeks is much closer to happiness, which refers to an agreeable sensation of the soul arising from prosperity or a pleasurable experience. However, eudaimonia, which Aristotle assigns a fundamental role in $N E$, is beyond the particular specifications just mentioned. First and foremost, he takes eudaimonia to be markedly pragmatic, ${ }^{2}$ so he insists that it is nothing but the ultimate end, which is achieved through training.

The effort involved in the process of training will reveal an internal power and makes it possible for one to achieve a particular form of knowledge. ${ }^{3}$ This is also an issue of paramount importance not only to the happiness of the individual, but also to the happiness of the society. In this sense, in Politics, Aristotle clearly expresses that "man is by nature political animal" (Aristotle, I997b: I253a2-3). In accordance with that, the happiness of the individual determines political success leading to the happiness of the society. Ethics in the basis of politics will bring people to the end of happiness. As far as we can understand from $N E$, this can be

\footnotetext{
Hereafter called as $N E$.

2 I would also like to point out that pragma (pragmatikos) like practice (praxis) etymologically comes from prassein, which means 'to do, to act, and to perform'. In this regard, it is not wrong to say that because, for Aristotle, happiness corresponds to something to which our actions are directed, he sees it as pragmatic.

3 Accordingly, 'human flourishing' has been preferred in order to provide this connotation of eudaimonia by many scholars.
} 
achieved just through having a deep knowledge on tools (pleasure, temperance, virtue, wisdom etc.), which enable human beings to realize the happiness. These tools are inevitable parts of the function of a human being. In this perspective, Aristotle asks the question what is the function of human being for the sake of seeking the characteristics of human being distinguishing her/him from other living beings. According to him, the most distinctive feature of human being distinguishing her/him characteristically from other living creatures is reason (logos) (Aristotle, NE: I098aI-5). Human beings get aware of good not given to their sensations, thanks to the reason. Accordingly, only they aim to achieve happiness or the highest good; they make a plan and act in accordance with this plan for the ultimate end. ${ }^{4}$

As a matter of course, the highest good that every action makes effort to achieve is the most basic concept of ethics. As mentioned above, Aristotle accepts happiness as the highest good at which all actions aim. In his ethical theory, reaching happiness is characterized as an end sufficient in itself. This end can be achieved just through virtuous actions, which signifies to a life at the exact center of reason. Aristotle's ethical theory implies that human beings become virtuous by living virtuously in accordance with the reason. In this connection, he suggests that virtue is the most basic requirement for happiness. This point is of paramount importance to grasp the nature of virtue in his ethics. Therefore, we need to focus on his thoughts on the soul in order to understand it. "The soul is defined by Aristotle as 'substance in one kind of what is' or else 'actuality of the first kind of a natural body having life potentially in'." (Bakalis, 2005: 152). For him, the soul has two main parts: Rational and nonrational (NE: IIO2a25-30).

Although Aristotle defines appetite (epithumia) and desire (orexis) as the non-rational, he argues that they are the parts of soul, which is capable of following the rational part of the soul. They are both listening to reason and obeying it. Accordingly, there are two kinds of virtue. He says the following: Virtue is of two sorts, virtue of thought and virtue of character. Virtue of thought arises and grows mostly from teaching, and

${ }^{4}$ For Aristotle, in a sense, this is the answer of the question "what could the human function be?" 
hence needs experience and time. Virtue of character (i.e. of ethos) results from habit (ethos); hence its name 'ethical', slightly varied from 'ethos'." (NE: IIO3aII-4). For instance, intellectual (dianoetikai) virtues (virtues of thought) are prudence and wisdom, and ethical (ethikai) virtues (virtues of character) are temperance and generosity. Aristotle puts:

For when we speak of someone's character we do not say that he is wise or has good comprehension, but that he is gentle or temperate. [Hence these are the virtues of character.] And yet, we also praise the wise person for his state, and the states that are praiseworthy are the ones we call virtues. [Hence wisdom is also a virtue.] (NE: IIO3a5-IO).

He clearly expresses that we can acquire ethical virtues and can achieve moral perfection through habits (NE: IIO3a2O-5). This means that human being is born in a certain predisposition both to realize ethical virtues and to pursue them. In this perspective, they are habits, which refer to lasting dispositions Therefore, in his system, knowledge (gnosis) is not a sufficient condition for ethics by itself. Practical reasoning has dominance over theoretical reasoning by means of virtues, since we possess them through experiences (empeiria). That is to say, theoretical reasoning is based on principles, while the human life in the world serves as a basis for practical reasoning. In this sense, in Aristotle's mind, ethics does not begin with principles, but with human action that advances towards habits which form a basis for the virtues or good character. In fact, the central aim of his ethics is to reveal the virtuous character state. He states:

Virtue, then, is a state that decides, [consisting] in a mean, the mean relative to us, which is defined by reference to reason, i.e., the reason by reference to which the intelligent person would define it. It is a mean between two vices, one of excess and one of deficiency (NE: Iro6b36-IIO7a3).

In $N E$, Aristotle also divides the rational part of the soul into two main parts, namely the scientific (epistemonikon) and the calculative (logistikon) or the deliberative (bouleutikon) (NE: II39a5-15). From his point of view, the proper management of deliberative aspect of the soul has a vital importance in revealing the virtuous habits. He puts it as follows:

As assertion and denial are to thought, so pursuit and avoidance are to de- 
sire. Now virtue of character is a state that decides; and decision is a deliberative desire. If, then, the decision is excellent, the reason must be true and the desire correct, so that what reason asserts is what desire pursues. This, then, is thought and truth concerned with action (NE: II39a2O-6).

At this stage, virtue is a permanent feature of the decision gained through a deliberative desire. Aristotle puts: "Now desire is for the goal. Hence decision is either understanding combined with desire or desire combined with thought; and what originates movement in this way is a human being." (NE: I139b4-7). Here, decision is one of the key concepts occupied a central place in NE. Probairesis, which is the counterpart to decision in Greek, means 'choosing (bairesis) before'. Aristotle states:

We have found, then, that what we decide to do is whatever action among those up to us we deliberate about and desire to do. Hence also decision will be deliberative desire to do an action that is up to us; for we have judged [that it is right] as a result of deliberation, our desire to do it expresses our wish. So much, then, for an outline of the sort of thing decision is about; it is about what promotes the end (NE: III3aio-5).

This shows that the stage in which alternatives are understood precedes decision. Therefore, decision is indissolubly linked with the five basic states or intellectual virtues by virtue of which the soul possesses the truth by the medium of assertion or denial. These are understanding (nous), craft (techne), philosophical wisdom (sophia), scientific knowledge (episteme), and prudence or practical wisdom (phronesis) (NE: I139bi5-8). Here, prudence is a virtue, which steps forward, since it perfects the deliberative part of the soul in terms of its relation with decision. The noun phronesis, which is the counterpart to prudence in Greek, is derived from the verb phronein. The verb phronein shows practical wisdom and intelligence in general. Aristotle handles phronesis in this sense. In addition to this, it is inextricably linked with things 'toward ends', so it is good deliberation. Virtue of character is an inevitable consequence of the good deliberation and decision reflects the good deliberation. As mentioned above, Aristotle points out that all virtues are habits related to decision. Whether one could be said to be prudent (phronimos) or not is decided by his/her decision resulting in a correct supposition about the end. Aristotle puts it as follows: 
Our deliberation may be unconditionally good or good only to the extent that it promotes some [limited] end. Hence unconditionally good deliberation is the sort that correctly promotes the unconditional end [i.e. the highest good], while the [limited] sort is the sort that correctly promotes some [limited] end. Hence, if having deliberated well is proper to an intelligent person, good deliberation will be the type of correctness that expresses what is expedient for promoting the end about which intelligence is true supposition (NE: II42b3O-3).

Aristotle indicates us that it is impossible to be indifferent to the problems on which our practical life is based. "What is the best way to live?" is a question, which is pertinent to the life of every person. This is one of the most serious questions of ethics. Another question, which is invoked by ethical problems and important at least as much as this question is "what should we devote ourselves to?" What kind of an action is proposed by these questions? Aristotle puts:

For living is apparently shared with plants, but what we are looking for is the special function of a human being; hence we should set aside the life of nutrition and growth. The life next in order is some sort of life of senseperception; but this too is apparently shared, with horse, ox and every animal. The remaining possibility, then, is some sort of life of action of the [part of the soul] that has reason (NE: II98a3-5).

Since happiness is both a complete end (teleios) and self-sufficient (autarkes) for him (NE: 1097a28-1098a18), this life of action is intended for happiness desired to be reached. In a sense, $N E$ is the product of a research on different tools for the end of happiness. As suggested above, prudence or phronesis is one of the most important tools of the happiness. Phronesis is generally translated into English such words as prudence, intelligence and practical wisdom. Which one of these words is an appropriate counterpart of phronesis is a different research topic. However, this uncertainty does not stem from its difficulty to be understood, but from the fact that it is a central concept for Aristotle's ethical theory. Well then, who are called prudent (phronimos)? Aristotle says:

It seems proper to an intelligent person (prudent) to be able to deliberate finely about what is good and beneficial for himself, not about some restricted area - e.g. about what promotes health or strength - but about what 
promotes living well in general. A sign of this is the fact that we call people intelligent about some [restricted area] whenever they calculate well to promote some excellent end, in an area where there is no craft. Hence where [living well] as a whole is concerned, the deliberative person will also be intelligent (NE: II4Oa25-9).

In $N E$, prudence points to a state possessing the truth, involving reason, concerned with what are good and beneficial for us. Therefore, prudence is superior to any ethical virtue and leads us to find appropriate mean to achieve the ethical virtues. Aristotle says the following:

For as soon as he (someone) has intelligence, which is a single state, he has all the virtues as well. And clearly, even if intelligence were useless in action, we would need it because it is the virtue of this part of the soul, and because the decision will not be correct without intelligence or without virtue. For virtue makes us reach the end in our action, while intelligence makes us reach what promotes the end (II45aI-5).

Aristotle thinks that prudence and virtue in the human life slowly develop by means of decisions we make. He draws our attention to the fact that we have the control (kratos) over non-rational desires in our decisions that make us be prudent. He says the following: “...the incontinent person acts on appetite, not on decision, but the continent person does the reverse and acts on decision, not appetite." (NE: IIIIbI3-5). On this basis, being continent (egkrates) is of vital importance for the correct decisions. In any case, the relationship between decision and prudence is based upon the concept of continent.

Aristotle clearly points out that "nor can the same person both intelligent and incontinent...an intelligent person must also at the same time be excellent in character, [and the incontinent person is not]." (NE: II52aro). This indicates that the reason and ethical virtues are by no means mutually exclusive. In the light of these considerations, finally, we can say that Aristotle thinks that advancement towards being prudent is inevitable if continence is internalized. Accordingly, the essential characteristic of being prudent manifests itself as the capacity to have full control over any decision. 


\section{References}

Aristotle (1985). Nicomachean Ethics (trans. T. Irwin). Indianapolis, IN: Hackett Publishing Company.

Aristotle (1997a). Metaphysics (trans. W. D. Ross). The Complete Works of Aristotle, vol. II (ed. J. Barnes). Oxford: Princeton University Press.

Aristotle (1997b). Politics (trans. B. Jowett). The Complete Works of Aristotle, vol. II (ed. J. Barnes). Oxford: Princeton University Press.

Bakalis, N. (2005). Handbook of Greek Philosophy: From Thales to the Stoics Analysis and Fragments. Victoria, BC: Trafford Publishing.

Öz: Aristoteles'in ahlak teorisi bize mutluluğun insan hayatını nasıl șekillendirdiğini anlatır. Amaca doğru hareket etme çabasını içerisinde barındıran mutluluk, özellikle nihai amacımızı elde etmemizi sağlayacak araçların ustalıkla kullanımında kendini gösterecektir. $\mathrm{Bu}$ çalıșma Aristoteles'in ahlak felsefesinin kavramsal çerçevesini anlamak adına, bu araçlardan ikisine karșıllk gelen basiret ile karar arasındaki ilișkiyi onun Nikomakbos'a Etik adlı eserinde nasıl temellendirdiğinin kısa bir izahını vermeyi amaçlamaktadır.

Anahtar Kelimeler: Aristoteles, Nikomakhos'a Etik, karar, basiret, mutluluk, erdem, ruh. 